\title{
Multiple Pit Defects in a Foldable Hydrophobic Intraocular Lens
}

\author{
Arjun Srirampur, MS, FRCS; Pasyanthi Balijepalli, MS
}

Anand Eye Institute, Hyderabad, India

ORCID:

Arjun Srirampur: https://orcid.org/0000-0002-3016-8336

J Ophthalmic Vis Res 2020; 15 (1): 118-119

Correspondence to:

Arjun Srirampur, MS, FRCS. Cornea, Cataract and Refractive surgery Anand Eye Institute, Habsiguda, Hyderabad 500007, India.

E-mail:sarjuneye@gmail.com

Received: 09-02-2019 Accepted: 29-05-2019

\begin{tabular}{|l|}
\hline \multicolumn{1}{|c|}{ Access this article online } \\
\hline Website: \\
https://knepublishing.com/index.php/JOVR \\
\hline DOI: \\
10.18502/jovr.v15i1.5963 \\
\hline
\end{tabular}

\section{Dear Editor,}

We are writing to share our observations regarding the article "Multiple pit defects of unknown etiology in a foldable hydrophobic intraocular lens" by Thabit et al. ${ }^{[1]}$ We would like to congratulate the authors for documenting this interesting phenomenon.

The authors mentioned no obvious reason for the formation of pit-like deposits on the anterior surface of the intraocular lens (IOL). We want to disagree with this statement in that IOL pit formation is a well-established phenomenon where opacification of hydrophilic acrylic IOLs occurs after corneal transplantations such as penetrating keratoplasty and Descemet's stripping endothelial keratoplasty (DSEK). ${ }^{[2]}$ Factors such as ocular inflammation and systemic comorbidities that affect ocular metabolism may contribute to the opacification of IOLs. ${ }^{[3]}$ Surgical interventions with the injection of different materials into the anterior chamber such as air or gas seem to increase the risk of IOL opacification, particularly in hydrophilic IOLs. The pits are limited to a more or less circular area of the anterior optical surface of the IOL corresponding to the zone of contact with the instilled air or gas.

Prolonged breakdown of the blood-aqueous barrier has been suggested as a contributory factor in IOL pit formation. The air in the anterior chamber causes dehydration of the anterior surface of the hydrophilic IOLs, and postoperative inflammation induces a metabolic change in the anterior chamber leading to an increase in aqueous proteins and calcium content that causes subsequent crystallization of the lens. ${ }^{[4]}$ It is our observation that opacification of hydrophilic IOLs develop in eyes that undergo DSEK and receive an air tamponade intraoperatively [Figures 1 and 2].

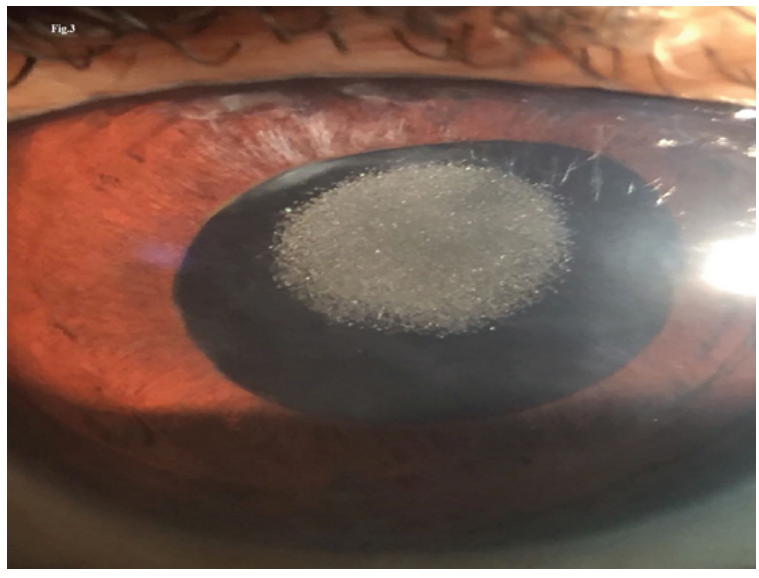

Figure 1. Slit lamp image on diffuse illumination showing the pits confined to the central undilated pupillary area of the intraocular lens.

This is an open access journal, and articles are distributed under the terms of the Creative Commons Attribution-NonCommercial-ShareAlike 4.0 License, which allows others to remix, tweak, and build upon the work non-commercially, as long as appropriate credit is given and the new creations are licensed under the identical terms.

How to cite this article: Srirampur A, Balijepalli P. Multiple Pit Defects in a Foldable Hydrophobic Intraocular Lens. J Ophthalmic Vis Res 2020;15:118119 


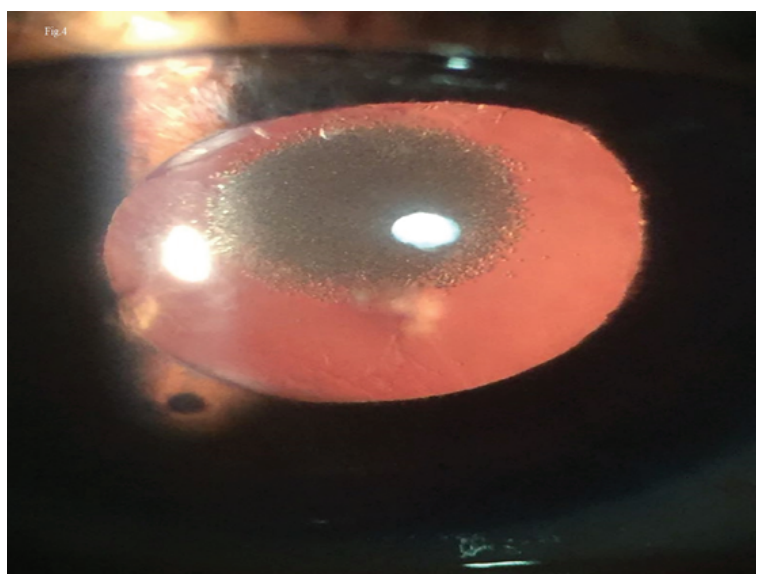

Figure 2. Polychromatic opacification of the pits on the anterior surface of the intraocular lens on retroillumination.

\section{REFERENCES}

1. Thabit A, Gatzioufas Z, McLintock C, Elalfy M, Hamada S. Multiple pit defects of unknown etiology in a foldable hydrophobic intraocular lens. J Ophthalmic Vis Res 2018;13:514-551.

2. Fellman MA, Werner L, Liu ET, Stallings S. Calcification of a hydrophilic acrylic intraocular lens after Descemetstripping endothelial keratoplasty: case report and laboratory analyses. J Cataract Refract Surg 2013;39:799-803.

3. Werner L, Wilbanks G, Ollerton A, Michelson J. Localized calcification of hydrophilic acrylic intraocular lenses in association with intracameral injection of gas. J Cataract Refract Surg 2012;38:720-721.

4. Dhittal A, Spalton DJ, Goyal S, Werner L. Calcification in hydrophilic intraocular lenses associated with injection of intraocular gas. Am J Ophthalmol 2012;153:1154-1160. 